\title{
Assessment of Long-Term Physicochemical Water Quality Variations by PCA Technique in Lake Hwajinpo, South Korea
}

\author{
Bal Dev Bhattrai', Sungjin Kwak ${ }^{1}$, Kwangsoon Choi $^{2}$, Woomyung Heo ${ }^{1}$ \\ ${ }^{1}$ Department of Earth and Environmental Engineering, Kangwon National University, Samcheok, Republic of Korea \\ ${ }^{2} \mathrm{~K}$-Water Institute, Korea Water Resources Corporation, Daejeon, Republic of Korea \\ Email: madebara@gmail.com, ksj@kangwon.ac.kr, kchoi@kwater.or.kr,woo@kangwon.ac.kr
}

How to cite this paper: Bhattrai, B.D., Kwak, S., Choi, K. and Heo, W. (2017) Assessment of Long-Term Physicochemical Water Quality Variations by PCA Technique in Lake Hwajinpo, South Korea. Journal of Environmental Protection, 8, 1636-1651.

https://doi.org/10.4236/jep.2017.813101

Received: November 20, 2017

Accepted: December 26, 2017

Published: December 29, 2017

Copyright $\odot 2017$ by authors and Scientific Research Publishing Inc. This work is licensed under the Creative Commons Attribution International License (CC BY 4.0).

http://creativecommons.org/licenses/by/4.0/

Open Access

\begin{abstract}
Physicochemical properties of water were analyzed to assess the long-term water quality variations in Lake Hwajinpo, Korea. Water quality data monitored from 1998 to 2015 was divided in three periods and descriptive statistics, correlation and rotated components were deducted using statistical procedures. Based on the results of analyses, water quality patterns in three periods (1998-2003, 2004-2009 and 2013-2015) were distinguishable from each other. Water parameters, Chlorophyll-a, total phosphorus, total nitrogen, dissolved oxygen and $\mathrm{pH}$, showed the highest mean values in the first period. On the other hand, conductivity and salinity in the second period and temperature and suspended solids in the third period showed the highest mean values. Principal component analysis (PCA) procedure was utilized to deduct the most significant parameters influencing water quality and observed that each period had different pattern of variables. Salinity and conductivity were the two variables highly contributing in first component/factor (F1) explaining $20.77 \%$ and $22.93 \%$ of the total variance in the first period and second period, respectively. But total phosphorus and chlorophyll-a were the two variables highly loading in F1 of the third period explaining $23.72 \%$ of total variance. These results revealed that the water quality of Lake Hwajinpo had different patterns of variations throughout the study period. Thus, PCA results could be valuable to understand the water quality status of water body and take proper steps to protect the water environment.
\end{abstract}

\section{Keywords}

Physicochemical Parameters, Coastal Lagoon, PCA, Lake Hwajinpo 


\section{Introduction}

Coastal lagoons are shallow water bodies separated from sea by barrier islands, coral reefs and sand bars. They have unique and rich habitats from sea to inland since they occupy the area between the sea and land. Along with lagoons, there may be habitats of barrier islands, spits, beaches, sand dunes, salt marshes and seagrasses to support biodiversity. The diverse ecosystem within the surrounding of lagoons plays important role to have high species of diversity and creates ecotones-area of transition between major habitats: marine, freshwater and terrestrial. The ecosystems of the lagoons were disturbed due to changes in climate and regional landscape [1] [2] [3]. Anthropogenic activities such as agriculture, aquaculture, urbanization, industrialization and recreational activities are major causes of water quality deterioration of lagoons. Eutrophication is the major threat to ecology and biological communities which arises because of high nutrient from point and non-point sources of pollution. Discharges from non-point source pollution such as agricultural and domestic water can cause the episodic eutrophication and algal blooms which can be toxic [4] [5] [6]. Lagoons receive sediments from rivers that flow into them and surface runoff. Therefore, coastal lagoons have a tendency to become filled with the sediments and thus disappear, in time, from the coastal landscape. Overuse of land and rapid industrialization are the main reason to the loss of lagoons area [7] [8]. The major threat to the existence and health of lagoons water body is human activities.

The lagoons in the Korean Peninsula are mainly distributed in the eastern coastline. Among the 57 natural lakes in this region 48 of them are marine origin natural lakes which were formed by sand dunes due to the ocean water currents [9] [10]. Lake Hwajinpo is one of the seven major lagoons in the eastern coast of Korea and the others are Youngrang, Kyoungpo, Sonji, Mae, Cheongcho and Gwangpo. The slope of the surface of the lake is gentle and the water level is stable throughout the year, and the wetland vegetation is well developed. Unlike the freshwater lake, Hwajinpo Lake is characterized by the combination of seawater and fresh water. It has the characteristics of brackish water. This lake has one inlet channel to exchange water with East Sea and can be categorized as the Choked lagoon [11]. Lake Hwajinpo was well protected lagoon in this region till 1991 because the public access was limited since it was designated as a military area. But later it was opened as a national recreation site and several infrastructures: museums, lodging and amusement facilities were built to attract visitors. These facilities along with increasing agricultural activities in the watershed causes high nutrient in the lagoon. The surface area of the lagoon has been slightly changed from $2.29 \mathrm{~km}^{2}$ in 1918 to $2.06 \mathrm{~km}^{2}$ in 2000 which is $90 \%$ of the initial lagoon area [7].

Water quality of coastal lagoons and other water bodies are very important for the ecosystem as well as human health. It is necessary to monitor and manage lagoons to abate any negative impact on its surrounding. A monitoring program is required to provide reliable measure of the quality of water bodies. Through data analysis, one can interpret and understand the nature of pollution [12]. The 
impact of natural and anthropogenic processes on the lagoon ecosystem could be identified by continuous monitoring and analyzing. Temporal and spatial water quality properties are helpful to recognize the changes and trend of lagoon water [13] [14]. Lake Hwajinpo and other major eastern coastal lagoons in Korea are regularly monitored since 1997 and ecosystem restoration efforts are made [15]. Previous literature of Lake Hwajinpo demonstrated eutrophication [10], limnological properties [16], landscape change [7] [9], water environment variation [17] and phytoplankton and trophic status [18].

The aim of this study is to assess the long-term temporal variations of physicochemical water quality of Lake Hwajinpo from 1998 to 2015. Descriptive water statistics and correlation were deducted and factor analysis (FA) was conducted to identify the important components or factor of water quality variables. The deduction of major parameters and grouping variables by multivariate techniques such as principal component analysis (PCA) enables to identify the sources of pollution [19] [20] [21]. Thus the result of this study will be helpful to water managers to understand the water quality status of Lake Hwajinpo and apply for further management.

\section{Materials and Methods}

\subsection{Study Area}

Lake Hwajinpo, a lagoon in the eastern coast of Korea, is located in Geojin township of Goseong County, Gangwon Province (Figure 1). The surface area of the lagoon is $2.06 \mathrm{~km}^{2}$ with average depth $1.2 \mathrm{~m}$ and divided into two parts, North and South which are connected by a narrow channel. The watershed area
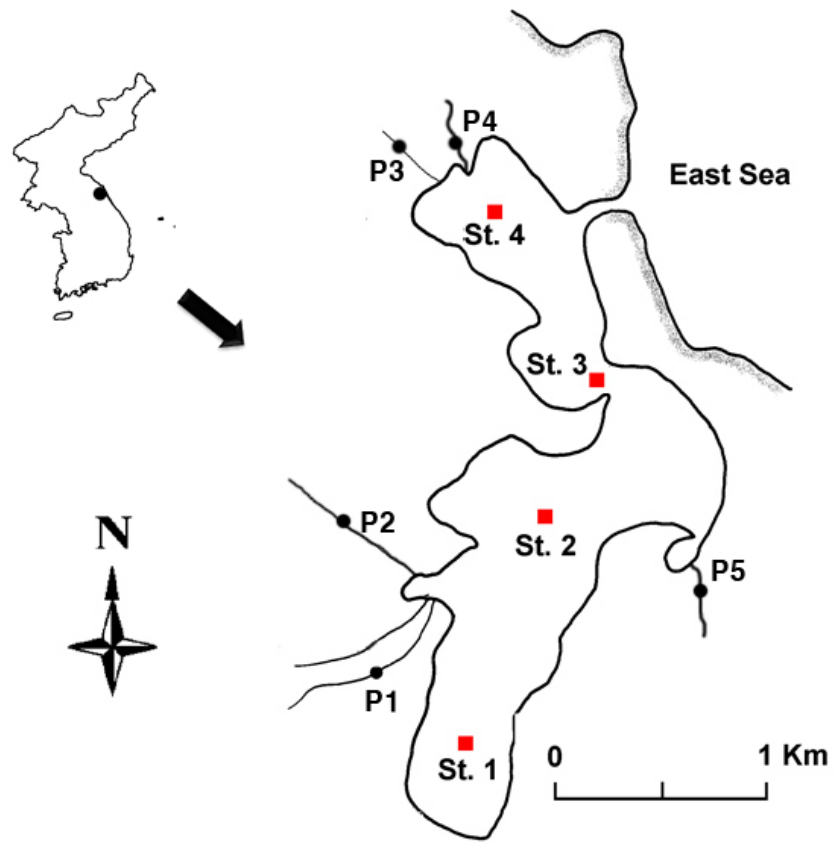

Figure 1. Map of the Lake Hwajinpo showing location in Korea and monitoring stations. The Geographic co-ordinates are Latitude $38^{\circ} 45-48^{\prime} \mathrm{N}$ and Longitude $128^{\circ} 42-44^{\prime}$. 


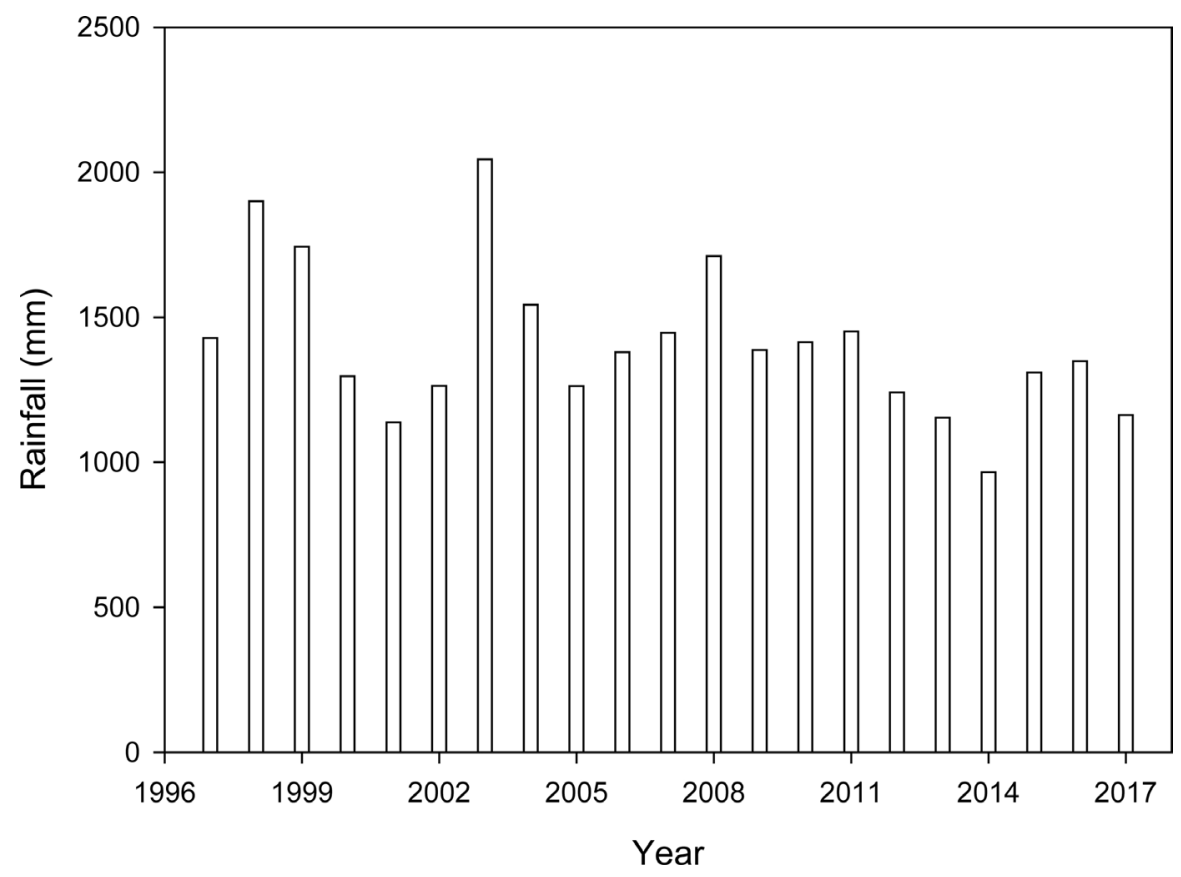

Figure 2. Annual rainfall in Goseong County, the basin of Lake Hwajinpo.

of the lagoon is $20.07 \mathrm{~km}^{2}$ and inflowing river system is $21 \mathrm{~km}$ in length of 5 small streams, Jungpyeong being the main stream. The North part is connected to the East Sea and relatively less polluted than the South part. The South part of the lagoon does not mix properly with sea water since horizontal mixing with North part is rare due to the narrow channel and receives more non-point source pollution through stream inflow and stormwater runoff. The South part, three times larger than the North part, largely receives pollutants from forest, farms and paddy fields. The average $\mathrm{N}$ and $\mathrm{P}$ loading generation in Lake Hwajinpo are 242 and $66 \mathrm{~kg} /$ day and average annual rainfall of last 20 years is 1410 $\mathrm{mm}$ [16] (Figure 2).

\subsection{Sampling and Measurements}

Water quality was monitored from 1998 to 2009 and 2013-2015 in a monthly basis in 65 episodes from four sites, two in North and two in South, except the months of severe winter. Water temperature (Temp), electric conductivity (EC), salinity (Sal), dissolved oxygen (DO), Secchi disk transparency (SD), $\mathrm{pH}$, suspended solids (SS), total phosphorus (TP), dissolved inorganic phosphorus (DIP), total nitrogen $(\mathrm{TN})$, nitrate nitrogen $\left(\mathrm{NO}_{3}-\mathrm{N}\right)$, ammonia nitrogen $\left(\mathrm{NH}_{3}-\mathrm{N}\right)$ and Chlorophyll-a (Chl-a) were the physicochemical parameters chosen. Lorenzen's (1967) method was used to calculate chlorophyll-a concentration. Filtered water was used to calculate dissolved nitrogen and phosphorus. TP was determined according to standard methods APHA [22], employing persulfate digestion and ascorbic acid method. TN was determined by the cadmium reduction method after persulfate digestion, using a flow injection auto-analyzer (BRAN-LUEBBE, Auto Analyzer3). Temperature, salinity, EC, $\mathrm{pH}$ and $\mathrm{DO}$ were measured in-situ 
with a multi-probe meter (YSI, 6000).

\subsection{Statistical Analyses}

The data was divided in three periods as 1998-2003, 2004-2009 and 2013-2015 to understand the water quality variations in different periods. Box and whiskers plots for five parameters were presented in (Figure 3). Several outlier values were visible in each period. Therefore we chose to perform non-parametric tests.
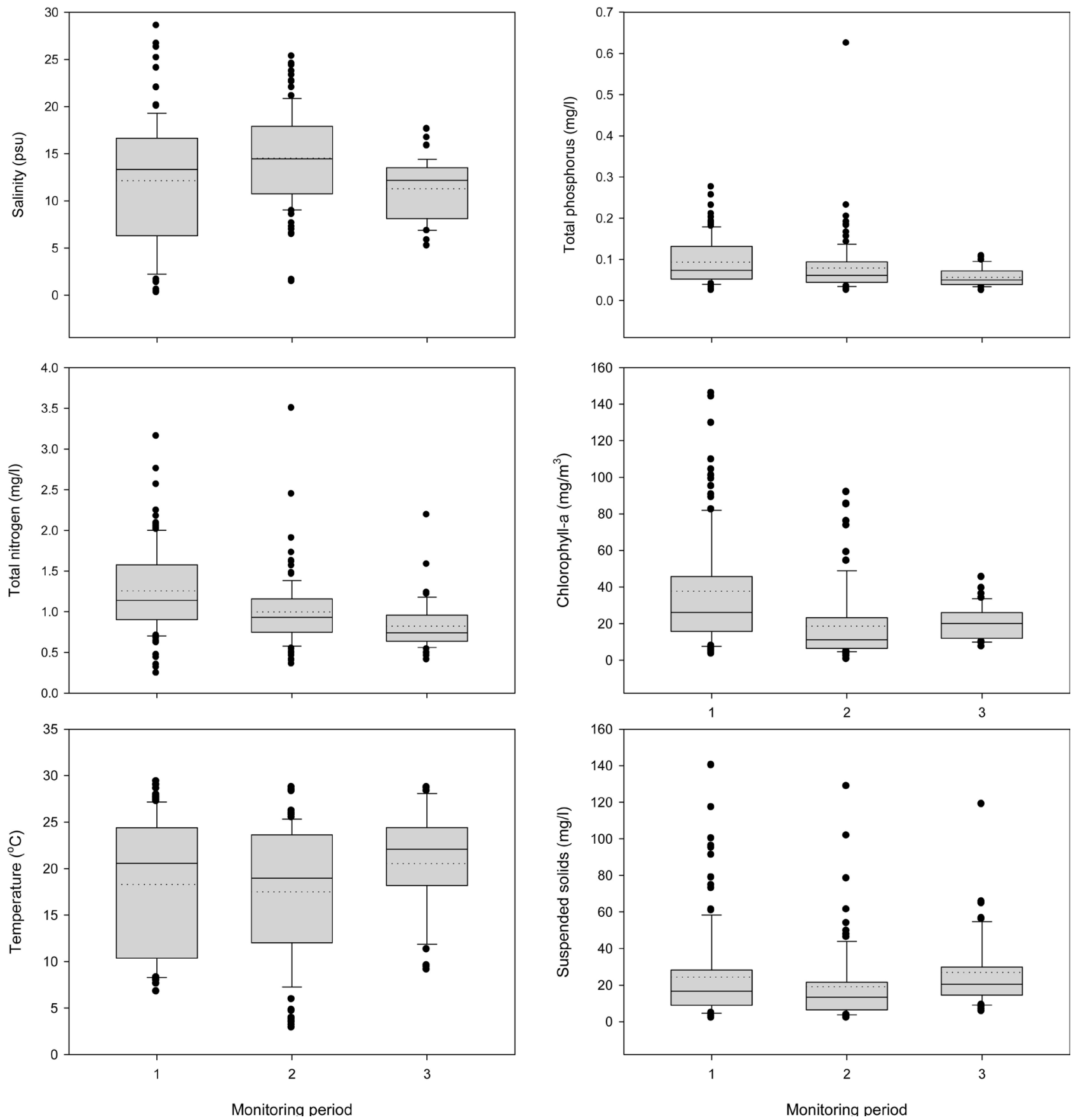

Figure 3. Box plots of water quality parameters. Mean, dotted line; median, dark line; box, $1^{\text {st }}$ and $3^{\text {rd }}$ quartiles; whiskers, mean \pm standard deviation; outliers, dark points. 
The non-parametric correlation and PCA/FA test were performed for statistical analysis in SPSS 19 software (IBM Corporation, Armonk, NY, USA). PCA helps to reduce dataset and it deducts dominant components which are valuable to have a better interpretation of variables. The details of these tests methods were detailed in these literatures [23] [24] [25].

\section{Results and Discussion}

\subsection{Descriptive Water Quality Patterns}

The descriptive statistics (mean, standard deviation etc.) physicochemical parameters of Lake Hwajinpo were presented in Tables 1-3 for the period of 1998-2003, 2004-2009 and 2013-2015, respectively. The results showed that the highest mean values of temperature, SD transparency and SS were in period of 2013-2015 and conductivity, salinity and $\mathrm{NO}_{3}-\mathrm{N}$ were in the period of 2004-2009. However, the highest mean values of DO, pH, Chl-a and nutrient components (TP, DIP and TN) were in the period of 1998-2003. There was not much variation of mean values of $\mathrm{NH}_{3}-\mathrm{N}$. The highest mean value of temperature was $20.6^{\circ} \mathrm{C}$ in the latter part of study period and the minimum was $17.51^{\circ} \mathrm{C}$ in 2004-2209. The highest mean values of SD and SS were $0.80 \mathrm{~m}$ and $27 \mathrm{mg} / \mathrm{L}$, respectively. Salinity, conductivity and $\mathrm{NO}_{3}-\mathrm{N}$ had the highest values as $25 \mathrm{psu}$, $2625 \mu \mathrm{s} / \mathrm{cm}$ and $0.08 \mathrm{mg} / \mathrm{L}$ in 2004-2009, respectively.

In the period of 1998-2003, the highest observed mean values of DO and $\mathrm{pH}$ were $10.56 \mathrm{mg} / \mathrm{L}$ and 9.3, respectively. Meanwhile, these two parameters had the lowest mean values in 2013-2015. The nutrient components had the maximum mean values in the earlier period of the study. And the lowest mean values were

Table 1. Descriptive statistics of surface water quality of Lake Hwajinpo from 1998-2003.

\begin{tabular}{|c|c|c|c|c|c|c|}
\hline Parameters & Minimum & Maximum & Mean & Standard Error & Standard Deviation & Observations \\
\hline Temp & 6.70 & 29.4 & 18.3 & 0.645 & 7.19 & 124 \\
\hline Cond & 427 & 47037 & 20761 & 983 & 10949 & 124 \\
\hline Sal & 0.23 & 30 & 13 & 0.637 & 7.10 & 124 \\
\hline DO & 0.56 & 27.12 & 10.56 & 0.386 & 4.29 & 124 \\
\hline $\mathrm{pH}$ & 1.47 & 69.6 & 9.331 & 0.499 & 5.55 & 124 \\
\hline SD & 0.20 & 1.7 & 0.656 & 0.030 & 0.34 & 124 \\
\hline $\mathrm{TP}$ & 0.02 & 0.28 & 0.093 & 0.005 & 0.05 & 124 \\
\hline DIP & 0.002 & 0.14 & 0.017 & 0.002 & 0.02 & 124 \\
\hline $\mathrm{TN}$ & 0.003 & 3.15 & 1.235 & 0.048 & 0.54 & 124 \\
\hline $\mathrm{NO}_{3} \mathrm{~N}$ & 0.040 & 1.00 & 0.061 & 0.011 & 0.13 & 124 \\
\hline $\mathrm{NH}_{3} \mathrm{~N}$ & 0.004 & 0.47 & 0.134 & 0.011 & 0.13 & 124 \\
\hline Chl-a & 3.00 & 146 & 37 & 2.810 & 31.29 & 124 \\
\hline SS & 2.00 & 140 & 24 & 2.237 & 24.71 & 122 \\
\hline Valid N (listwise) & & & & & & 122 \\
\hline
\end{tabular}

Temp, water temperature $\left({ }^{\circ} \mathrm{C}\right)$; SD, Secchi disk transparency $(\mathrm{m})$; Sal, Salinity (psu); DO, dissolved oxygen $(\mathrm{mg} / \mathrm{L})$; COD, chemical oxygen demand (mg/L); SS, suspended solids (mg/L); TP, total phosphorus (mg/L); $\mathrm{DIP}$, dissolved inorganic phosphorus $(\mathrm{mg} / \mathrm{L})$; $\mathrm{TN}$, total nitrogen $(\mathrm{mg} / \mathrm{L}) ; \mathrm{NO}_{3}-\mathrm{N}$, nitrate nitrogen $(\mathrm{mg} / \mathrm{L})$; $\mathrm{NH}_{3}-\mathrm{N}$, ammonia nitrogen $(\mathrm{mg} / \mathrm{L})$ and Chl-a, chlorophyll-a $\left(\mathrm{mg} / \mathrm{m}^{3}\right)$. 
B. D. Bhattrai et al.

Table 2. Descriptive statistics of surface water quality of Lake Hwajinpo from 2004-2009.

\begin{tabular}{|c|c|c|c|c|c|c|}
\hline Parameters & Minimum & Maximum & Mean & Standard Error & Standard Deviation & Observations \\
\hline Temp & 2.9 & 28.7 & 17.51 & 0.71 & 7.07 & 98 \\
\hline Cond & 2625 & 39760 & 23787 & 748 & 7406 & 98 \\
\hline Sal & 1.4 & 25.0 & 15.0 & 0.49 & 4.86 & 98 \\
\hline DO & 3.1 & 14.72 & 8.95 & 0.25 & 2.44 & 98 \\
\hline $\mathrm{pH}$ & 6.84 & 9.9 & 8.45 & 0.058 & 0.574 & 98 \\
\hline SD & 0.3 & 1.7 & 0.70 & 0.053 & 0.525 & 97 \\
\hline TP & 0.02 & 0.62 & 0.08 & 0.070 & 0.070 & 97 \\
\hline DIP & 0.006 & 0.18 & 0.01 & 0.002 & 0.020 & 97 \\
\hline $\mathrm{TN}$ & 0.35 & 3.5 & 1.00 & 0.043 & 0.427 & 97 \\
\hline $\mathrm{NO}_{3} \mathrm{~N}$ & 0.008 & 0.84 & 0.08 & 0.013 & 0.127 & 97 \\
\hline $\mathrm{NH}_{3} \mathrm{~N}$ & 0.003 & 1.84 & 0.13 & 0.024 & 0.233 & 97 \\
\hline Chl-a & 0.267 & 92.0 & 18.0 & 2.00 & 20.0 & 97 \\
\hline SS & 1.8 & 129 & 19.0 & 2.23 & 21.0 & 86 \\
\hline Valid N (listwise) & & & & & & 86 \\
\hline
\end{tabular}

Table 3. Descriptive statistics of surface water quality of Lake Hwajinpo from 2013-2015.

\begin{tabular}{|c|c|c|c|c|c|c|}
\hline Parameters & Minimum & Maximum & Mean & Standard Error & Standard deviation & Observations \\
\hline Temp & 9.1 & 28.7 & 20.6 & 0.7 & 5.3 & 59 \\
\hline Cond & 11840 & 29079 & 18491 & 697 & 5351 & 59 \\
\hline Sal & 5.2 & 17.6 & 11.3 & 0.4 & 3.2 & 59 \\
\hline DO & 5.4 & 12.1 & 8.6 & 0.2 & 1.7 & 59 \\
\hline $\mathrm{pH}$ & 6.7 & 9.7 & 8.1 & 0.2 & 1.2 & 59 \\
\hline $\mathrm{SD}$ & 0.4 & 1.6 & 0.80 & 0.01 & 0.3 & 59 \\
\hline $\mathrm{TP}$ & 0.020 & 0.110 & 0.057 & 0.003 & 0.022 & 59 \\
\hline DIP & 0.001 & 0.020 & 0.006 & 0.001 & 0.006 & 59 \\
\hline $\mathrm{TN}$ & 0.404 & 2.190 & 0.823 & 0.038 & 0.295 & 59 \\
\hline $\mathrm{NO}_{3} \mathrm{~N}$ & 0.006 & 0.390 & 0.056 & 0.014 & 0.109 & 59 \\
\hline $\mathrm{NH}_{3} \mathrm{~N}$ & 0.001 & 1.130 & 0.130 & 0.027 & 0.207 & 59 \\
\hline Chl-a & 7.15 & 45.20 & 20 & 1.57 & 12.06 & 59 \\
\hline SS & 6 & 119 & 27 & 3 & 20 & 59 \\
\hline \multicolumn{2}{|c|}{ Valid N (listwise) } & & & & & 59 \\
\hline
\end{tabular}

in the latter period as well. The highest mean values of nutrient components TP, DIP and TN were $0.093 \mathrm{mg} / \mathrm{L}, 0.017 \mathrm{mg} / \mathrm{L}$ and $1.235 \mathrm{mg} / \mathrm{L}$, respectively. Chl-a had the highest mean value $37 \mathrm{mg} / \mathrm{m}^{3}$ in $1998-2003$ and the lowest mean value $19 \mathrm{mg} / \mathrm{m}^{3}$ in $2004-2009$.

\subsection{Relations between Water Quality Parameters}

Spearman's rank correlation coefficients matrices of water variables for three periods are presented in Tables 4-6. Overall, correlation coefficients values ( $\mathrm{p}<$ 
Table 4. Spearman's rank correlation and p-value of water quality variables in Hwajinpo from 1998-2003.

\begin{tabular}{|c|c|c|c|c|c|c|c|c|c|c|c|c|}
\hline Parameters & Cond & Sal & DO & $\mathrm{pH}$ & SD & TP & DIP & $\mathrm{TN}$ & $\mathrm{NO}_{3} \mathrm{~N}$ & $\mathrm{NH}_{3} \mathrm{~N}$ & Chl-a & SS \\
\hline Temp & -0.08 & -0.07 & $-0.235^{\star}$ & 0.06 & -0.08 & $0.306^{* *}$ & 0.07 & 0.19 & $0.320^{* *}$ & -0.17 & $0.279^{\star *}$ & -0.01 \\
\hline Cond & & $0.998^{\star *}$ & -0.18 & 0.12 & 0.06 & -0.05 & $-0.224^{\star}$ & 0.12 & $-0.372^{\star *}$ & $-0.330^{* *}$ & -0.19 & $0.265^{*}$ \\
\hline Sal & & & -0.19 & 0.11 & 0.07 & -0.05 & $-0.218^{*}$ & 0.11 & $-0.360^{* *}$ & $-0.329^{\star *}$ & $-0.200^{*}$ & $0.275^{*}$ \\
\hline DO & & & & $0.510^{* *}$ & -0.13 & 0.03 & 0.08 & $0.263^{\star *}$ & 0.14 & 0.15 & 0.16 & 0.00 \\
\hline $\mathrm{pH}$ & & & & & -0.13 & $0.225^{*}$ & 0.00 & $0.279^{\star *}$ & 0.10 & -0.10 & 0.17 & 0.12 \\
\hline $\mathrm{SD}$ & & & & & & $-0.366^{* *}$ & $0.248^{\star}$ & $-.348^{* *}$ & -0.04 & 0.09 & $-0.351^{* *}$ & $-0.341^{* *}$ \\
\hline $\mathrm{TP}$ & & & & & & & $0.206^{*}$ & $0.548^{\star *}$ & 0.02 & -0.08 & $0.453^{* *}$ & $0.353^{* *}$ \\
\hline DIP & & & & & & & & $0.233^{*}$ & 0.07 & $0.250^{\star}$ & $-0.251^{*}$ & 0.06 \\
\hline $\mathrm{TN}$ & & & & & & & & & 0.19 & 0.01 & $0.327^{* *}$ & 0.17 \\
\hline $\mathrm{NO}_{3} \mathrm{~N}$ & & & & & & & & & & 0.10 & 0.07 & -0.03 \\
\hline $\mathrm{NH}_{3} \mathrm{~N}$ & & & & & & & & & & & 0.14 & -0.07 \\
\hline Chl-a & & & & & & & & & & & & 0.18 \\
\hline
\end{tabular}

Significance level $(\alpha)=0.05$, two-tailed. ${ }^{*} \mathrm{p}<0.01$ and ${ }^{* *} \mathrm{p}<0.05, \mathrm{p}>|\mathrm{r}|$ under H0:Rho $=0$.

Table 5. Spearman's rank correlation and p-value of water quality variables in Hwajinpo from 2004-2009.

\begin{tabular}{|c|c|c|c|c|c|c|c|c|c|c|c|c|}
\hline Parameters & Cond & Sal & DO & $\mathrm{pH}$ & SD & $\mathrm{TP}$ & DIP & $\mathrm{TN}$ & $\mathrm{NO}_{3} \mathrm{~N}$ & $\mathrm{NH}_{3} \mathrm{~N}$ & Chl-a & SS \\
\hline Temp & -0.08 & -0.071 & $-0.235^{\star}$ & 0.06 & -0.082 & $0.306^{* *}$ & 0.065 & 0.192 & $0.320^{* *}$ & -0.166 & $0.279^{* *}$ & -0.009 \\
\hline Cond & & $0.998^{* *}$ & -0.181 & 0.116 & 0.064 & -0.053 & $-0.224^{*}$ & 0.116 & $-0.372^{\star *}$ & $-0.330^{* *}$ & -0.185 & $0.265^{\star}$ \\
\hline Sal & & & -0.191 & 0.108 & 0.068 & -0.052 & $-0.218^{*}$ & 0.109 & $-0.360^{* *}$ & $-0.329^{* *}$ & $-0.200^{*}$ & $0.275^{*}$ \\
\hline DO & & & & $0.510^{* *}$ & -0.126 & 0.029 & 0.083 & $0.263^{* *}$ & 0.136 & 0.153 & 0.157 & 0.003 \\
\hline $\mathrm{pH}$ & & & & & -0.129 & $0.225^{*}$ & 0.002 & $0.279^{* *}$ & 0.097 & -0.1 & 0.165 & 0.115 \\
\hline SD & & & & & & $-0.366^{* *}$ & $0.248^{*}$ & $-0.348^{* *}$ & -0.036 & 0.085 & $-0.351^{\star *}$ & $-0.341^{\star \star}$ \\
\hline $\mathrm{TP}$ & & & & & & & $0.206^{*}$ & $0.548^{* *}$ & 0.021 & -0.078 & $0.453^{* *}$ & $0.353^{* *}$ \\
\hline DIP & & & & & & & & $0.233^{*}$ & 0.067 & $0.250^{*}$ & $-0.251^{*}$ & 0.059 \\
\hline $\mathrm{TN}$ & & & & & & & & & 0.192 & 0.008 & $.327^{* *}$ & 0.167 \\
\hline $\mathrm{NO}_{3} \mathrm{~N}$ & & & & & & & & & & 0.103 & 0.071 & -0.027 \\
\hline $\mathrm{NH}_{3} \mathrm{~N}$ & & & & & & & & & & & 0.14 & -0.072 \\
\hline Chl-a & & & & & & & & & & & & 0.181 \\
\hline
\end{tabular}

Table 6. Spearman's rank correlation and p-value of water quality variables in Hwajinpo from 2013-2015.

\begin{tabular}{|c|c|c|c|c|c|c|c|c|c|c|c|c|}
\hline Parameters & Cond & Sal & DO & $\mathrm{pH}$ & SD & TP & DIP & $\mathrm{TN}$ & $\mathrm{NO}_{3} \mathrm{~N}$ & $\mathrm{NH}_{3} \mathrm{~N}$ & Chl-a & SS \\
\hline Temp & $0.381^{* *}$ & 0.195 & $-0.720^{\star *}$ & -0.004 & -0.214 & $0.279^{*}$ & 0.142 & $-0.273^{*}$ & 0.047 & 0.091 & -0.194 & -0.194 \\
\hline Cond & & $0.865^{* *}$ & -0.255 & 0.037 & -0.21 & 0.144 & -0.104 & $-0.485^{\star *}$ & $-0.372^{\star *}$ & $0.339^{* *}$ & $-0.269^{*}$ & 0.057 \\
\hline Sal & & & -0.153 & -0.104 & $-0.321^{*}$ & 0.061 & -0.133 & $-0.481^{\star *}$ & $-0.492^{\star *}$ & $0.337^{* *}$ & $-0.297^{\star}$ & 0.114 \\
\hline DO & & & & 0.248 & 0.079 & $-0.352^{\star *}$ & -0.247 & 0.203 & -0.028 & 0.112 & 0.082 & 0.206 \\
\hline $\mathrm{pH}$ & & & & & $-0.275^{\star}$ & 0.215 & $-0.567^{\star *}$ & $0.382^{\star *}$ & $0.457^{\star *}$ & -0.148 & 0.204 & 0.137 \\
\hline SD & & & & & & $-0.511^{* *}$ & $0.334^{\star *}$ & -0.009 & 0.046 & 0.069 & $-0.315^{*}$ & -0.243 \\
\hline $\mathrm{TP}$ & & & & & & & -0.124 & $0.285^{\star}$ & 0.224 & -0.171 & $0.649^{* *}$ & 0.04 \\
\hline DIP & & & & & & & & -0.111 & -0.195 & 0.231 & -0.14 & $-0.471^{\star *}$ \\
\hline $\mathrm{TN}$ & & & & & & & & & $0.595^{* *}$ & -0.159 & $0.350^{* *}$ & -0.19 \\
\hline $\mathrm{NO}_{3} \mathrm{~N}$ & & & & & & & & & & $-0.304^{*}$ & $0.295^{*}$ & -0.001 \\
\hline $\mathrm{NH}_{3} \mathrm{~N}$ & & & & & & & & & & & $-0.302^{*}$ & -0.028 \\
\hline Chl-a & & & & & & & & & & & & 0.214 \\
\hline
\end{tabular}


0.05 , two-tailed, in bold) were not very high; however, salinity and conductivity demonstrated highly significant positive correlation for all three periods. DO showed highly significant negative correlation with temperature with the highest coefficient 0.72 in 2013-2015. DO showed significant positive correlation with $\mathrm{pH}$ with coefficient values nearly 0.50 in the first two periods. SS correlation with TP and TN were positive and Chl-a and SS were negative. These correlation coefficients were in the range of $0.30-0.50$. TP was positively correlated with TN with all three periods with coefficients approximately 0.50 . TP showed significant correlations with SS in the first two periods but no correlation in 2013-2015. Chl-a demonstrated significant positive correlation with TP and the highest coefficient values was 0.649 in 2013-2015. Similarly, Chl-a showed positive correlation with $\mathrm{TN}$ and the values were approximately 0.32 . The positive correlations of SS with nutrient components and Chl-a might be related to the discharges of pollutants in lagoon from natural and anthropogenic sources [23] [26].

\subsection{Identification of Significantly Important Variables Affecting Water Quality}

PCA procedure was applied on each datasets to deduct important variables for each factor. The factors with Eigen value more than 1 (scree plots, Figure 4, Figure 5 and Figure 6) were retracted PCA produced six components/factors (Figure 4) of the first period (1998-2003) which explained $74.07 \%$ of total variance. The first three factors explained nearly $50 \%$ of the total variance $(20.77 \%$, $16.96 \%$ and $11.01 \%$ for F1, F2 and F3, respectively). F1 showed the highest positive correlation with Cond and salinity as 0.983 and 0.981 , respectively. F2 was

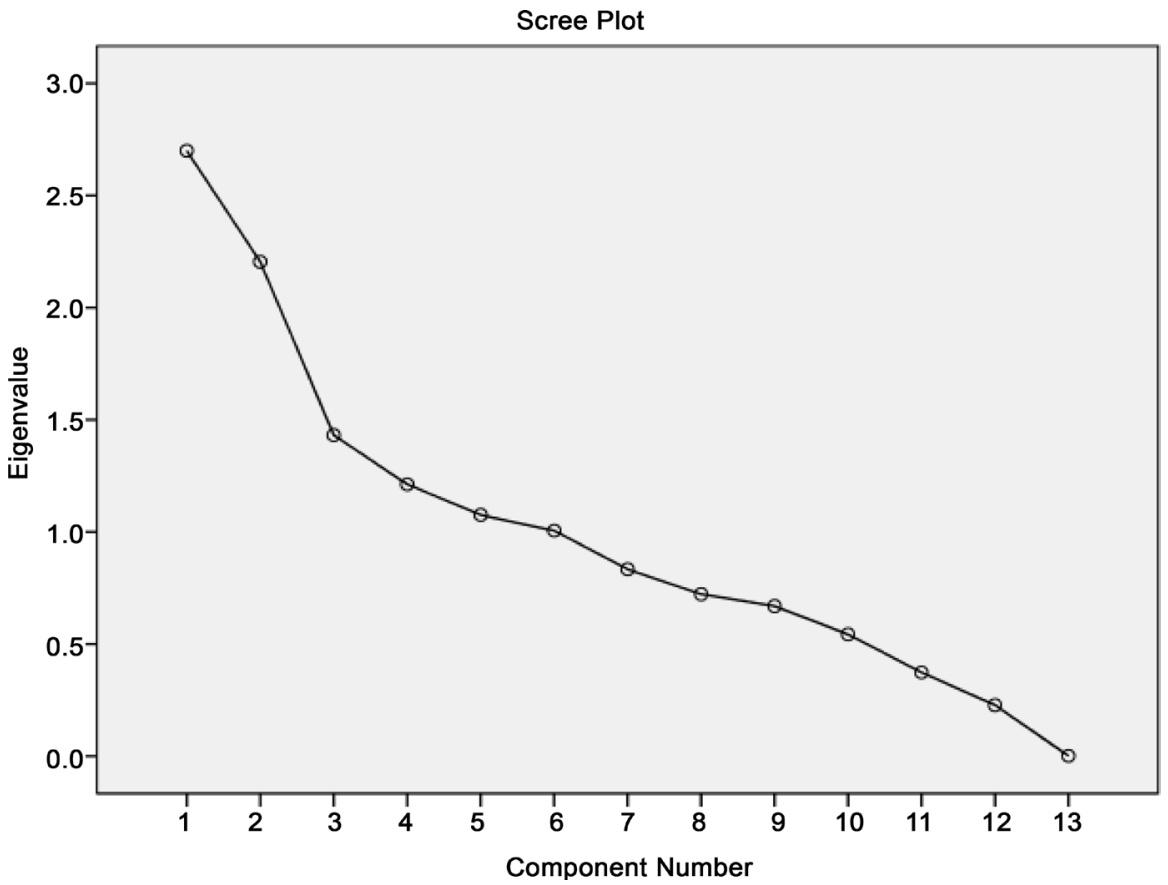

Figure 4. Scree plot (1998-2003). 


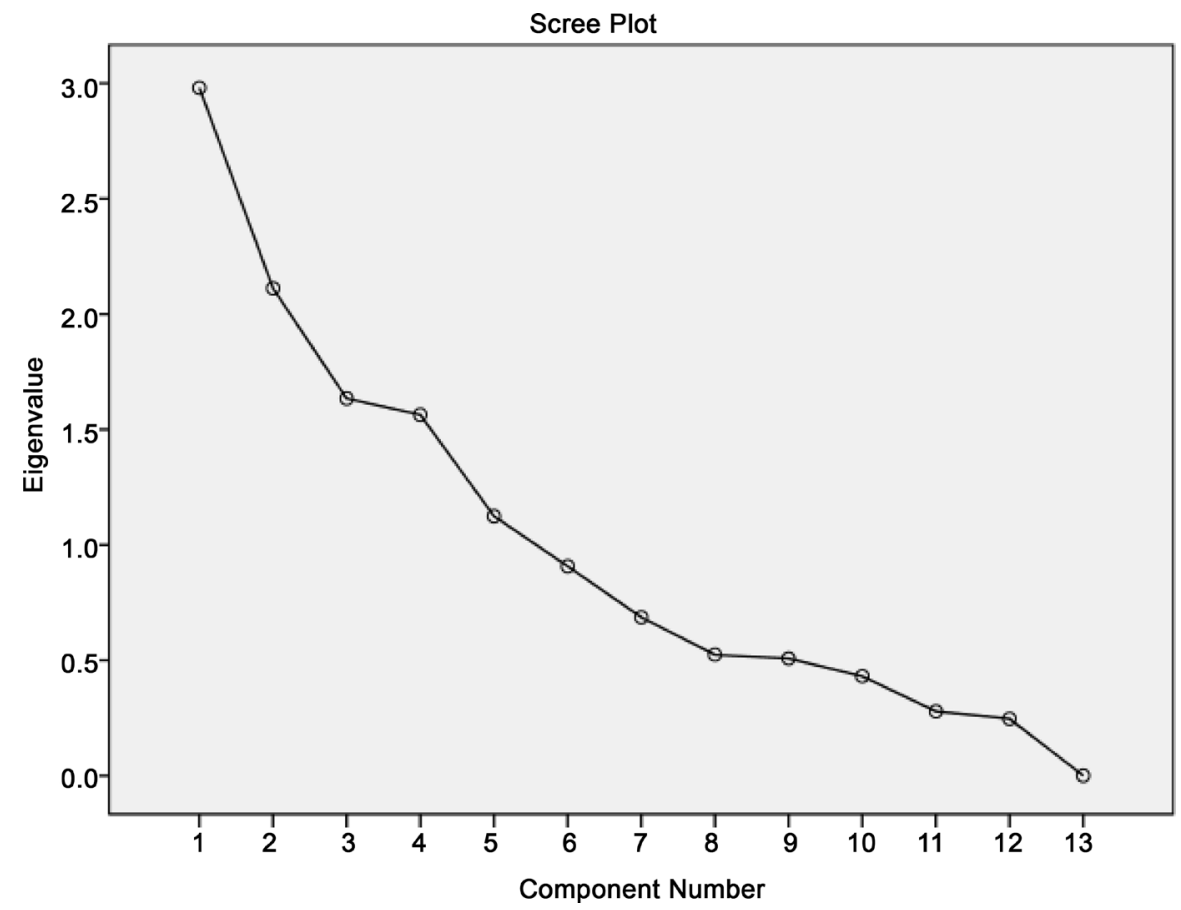

Figure 5. Sree plot of 2004-2009.

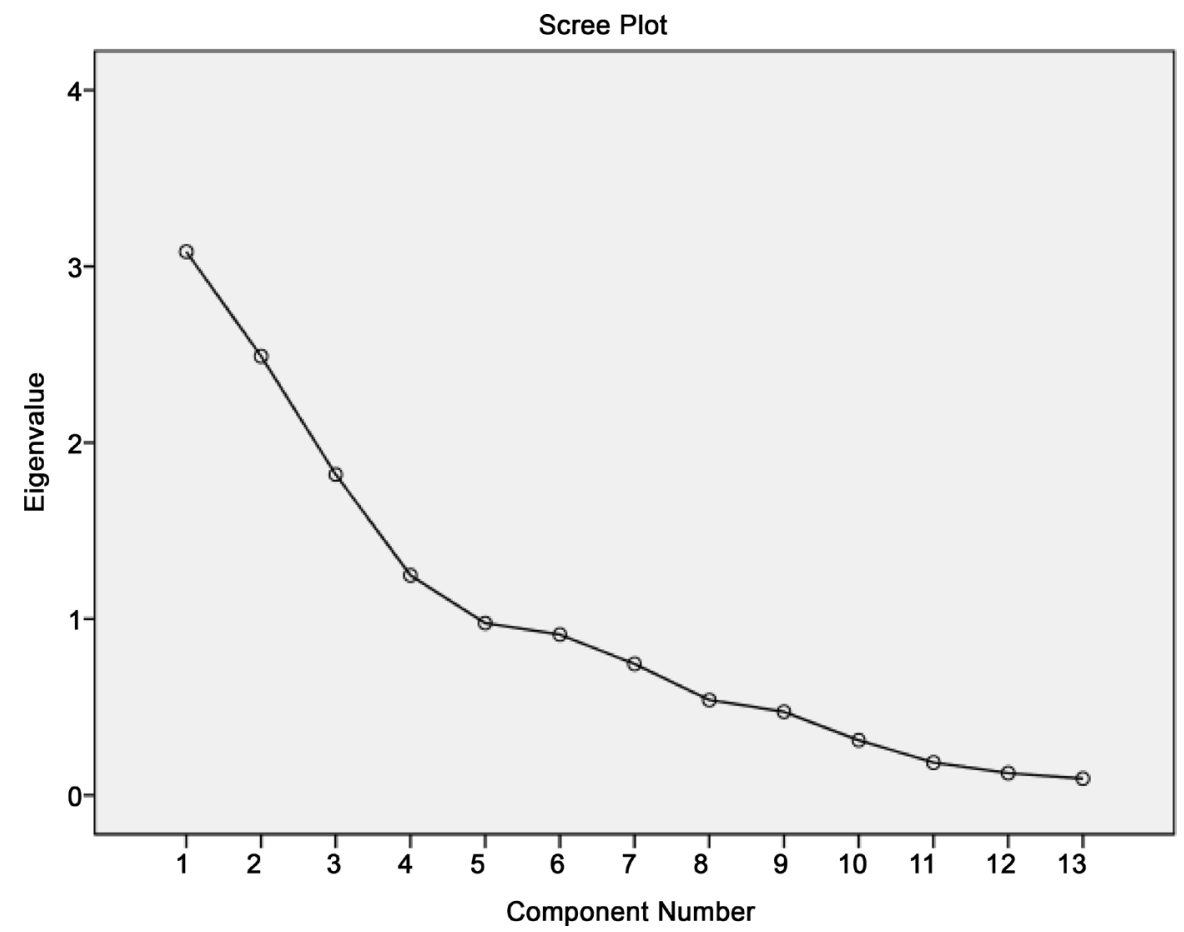

Figure 6. Scree plot of 2013-2015.

positively correlated with $\mathrm{TN}$ and Chl-a and negatively correlated with SD. Third factor showed positive correlation with Temp and TP and negative correlation with SS. F4, F5 and F6 showed positive correlation $\mathrm{pH}$ and $\mathrm{NH}_{3}-\mathrm{N}$, DIP and SS and DO, respectively (Table 7). The first factor of 2004-2009 data explained $22.93 \%$ of the total variance and largely and positively contributed by 
Table 7. Rotated component matrix (a) of Lake Hwajinpo from1998-2003.

\begin{tabular}{|c|c|c|c|c|c|c|}
\hline \multirow[b]{2}{*}{ Parameters } & \multicolumn{6}{|c|}{ Factor $(\mathrm{F}) \mathrm{s}$} \\
\hline & 1 & 2 & 3 & 4 & 5 & 6 \\
\hline Temp & -0.085 & 0.092 & 0.746 & -0.171 & 0.155 & -0.030 \\
\hline Cond & 0.930 & 0.027 & -0.071 & -0.147 & 0.007 & -0.139 \\
\hline Sal & 0.929 & 0.027 & -0.067 & -0.132 & -0.003 & -0.144 \\
\hline DO & -0.048 & -0.035 & -0.006 & -0.081 & -0.035 & 0.926 \\
\hline $\mathrm{pH}$ & -0.132 & 0.035 & -0.226 & 0.774 & -0.039 & 0.080 \\
\hline $\mathrm{SD}$ & 0.238 & -0.675 & 0.070 & 0.097 & -0.047 & 0.129 \\
\hline $\mathrm{TP}$ & 0.163 & 0.325 & 0.679 & 0.246 & 0.182 & 0.091 \\
\hline DIP & 0.044 & -0.016 & 0.243 & 0.041 & 0.905 & -0.059 \\
\hline $\mathrm{TN}$ & 0.316 & 0.770 & 0.224 & 0.165 & 0.035 & -0.185 \\
\hline $\mathrm{NO}_{3} \mathrm{~N}$ & -0.669 & 0.014 & -0.057 & -0.052 & -0.133 & -0.231 \\
\hline $\mathrm{NH}_{3} \mathrm{~N}$ & -0.055 & -0.042 & 0.278 & 0.690 & 0.055 & -0.213 \\
\hline Chl-a & 0.053 & 0.850 & 0.128 & -0.018 & -0.017 & 0.217 \\
\hline SS & 0.241 & 0.235 & -0.603 & -0.117 & 0.538 & 0.079 \\
\hline \multicolumn{7}{|c|}{ Variance explained by each factor } \\
\hline Factors & 1 & 2 & 3 & 4 & 5 & 6 \\
\hline$\%$ of Variance & 20.77 & 16.96 & 11.01 & 9.33 & 8.28 & 7.74 \\
\hline \multicolumn{6}{|c|}{ Total variance explained \% } & 74.07 \\
\hline
\end{tabular}

Extraction method: Principal component analysis. Rotation method: Varimax with Kaiser Normalization. a: Rotation converged in 6 iterations.

Cond and salinity. F2 explained $16.23 \%$ of the total variance and positively correlated with Temp, TP and Chl-a and negatively correlated with SD. F3 was correlated positively with $\mathrm{DO}$ and $\mathrm{pH}$. F4 and explained $12.03 \%$ and $8.65 \%$ of the total variance and positively contributed by TN and $\mathrm{NH}_{3} \mathrm{~N}$ and DIP and SS, respectively. The total variance explained was $72.42 \%$ (Table 8). Factor results of 2013-2015 data were presented in Table 9 where total variance explained was $66.46 \%$ by four factors. The first factor explained $23.72 \%$ of the total variance. F1 showed positive correlations with TP (0.887) and Chl-a (0.788) and negative correlations with SD (0.667). F2 was positively contributed by $\mathrm{DO}$ and $\mathrm{NO}_{3} \mathrm{~N}$ and negatively contributed by DIP. F3 explained $13.99 \%$ of the total variance and heavily contributed by Cond and salinity. $\mathrm{TN}$ and $\mathrm{NH}_{3} \mathrm{~N}$ were the main parameters correlated with $\mathrm{F} 4$ with positive coefficients.

\subsection{Discussion}

Lake Hwajinpo water quality demonstrated in this study showed wide variations in three periods in 1998-2015. The mean temperature decreased in the second period and increased in the third period (2013-205) with the highest (in bold) temperature $20.6^{\circ} \mathrm{C}$. Lagoon surface water temperature is an important factor to 
Table 8. Rotated component matrix (a) of Hwajinpo from 2004-2009.

\begin{tabular}{cccccc}
\hline \multirow{2}{*}{ Parameters } & \multicolumn{5}{c}{ Factors } \\
\cline { 2 - 6 } & 1 & 2 & 3 & 4 & 5 \\
\hline Temp & -0.096 & $\mathbf{0 . 7 2 6}$ & -0.25 & -0.151 & -0.264 \\
Cond & $\mathbf{0 . 9 8 3}$ & -0.054 & -0.012 & -0.030 & 0.009 \\
Sal & $\mathbf{0 . 9 8 1}$ & -0.056 & -0.019 & -0.038 & 0.009 \\
DO & -0.172 & 0.045 & $\mathbf{0 . 8 2 5}$ & 0.204 & 0.009 \\
pH & 0.092 & 0.186 & 0.812 & -0.023 & -0.052 \\
SD & -0.002 & -0.583 & -0.191 & 0.071 & -0.295 \\
TP & -0.078 & 0.706 & 0.184 & 0.245 & 0.278 \\
DIP & -0.154 & 0.023 & -0.223 & 0.134 & 0.734 \\
TN & 0.164 & 0.367 & 0.122 & 0.805 & 0.021 \\
NO ${ }_{3} \mathrm{~N}$ & -0.388 & 0.182 & 0.203 & 0.422 & 0.228 \\
NH ${ }_{3} \mathrm{~N}$ & -0.203 & -0.347 & 0.022 & $\mathbf{0 . 8 0 6}$ & -0.043 \\
Chl-a & -0.088 & $\mathbf{0 . 6 6 8}$ & 0.385 & 0.145 & -0.165 \\
SS & 0.122 & 0.034 & 0.112 & -0.079 & 0.878 \\
& Variance explained by each factor & & \\
Factors & 1 & 2 & 3 & 4 & 5 \\
\% of Variance & 22.93 & 16.25 & 12.57 & 12.03 & 8.65 \\
\%Total variance explained & & & 72.42 & \\
\hline
\end{tabular}

Extraction method: Principal component analysis. Rotation method: Varimax with Kaiser Normalization. a: Rotation converged in 5 iterations.

Table 9. Rotated component matrix (a) of Hwajinpo from 2013-2015.

\begin{tabular}{ccccc}
\hline \multirow{2}{*}{ Parameters } & \multicolumn{3}{c}{ Factors } \\
\cline { 2 - 5 } Temp & 1 & 2 & 3 & 4 \\
Cond & -0.090 & -0.756 & 0.238 & 0.146 \\
Sal & 0.002 & -0.176 & 0.847 & 0.113 \\
DO & 0.041 & -0.119 & 0.893 & -0.037 \\
pH & -0.191 & 0.833 & -0.026 & -0.043 \\
SD & 0.411 & 0.236 & 0.134 & 0.305 \\
TP & -0.667 & 0.126 & -0.239 & 0.062 \\
DIP & 0.887 & -0.206 & 0.009 & 0.195 \\
TN & -0.476 & -0.577 & -0.160 & 0.009 \\
NO ${ }_{3} \mathrm{~N}$ & 0.228 & 0.233 & -0.388 & 0.781 \\
$\mathrm{NH}_{3} \mathrm{~N}$ & -0.061 & 0.594 & -0.440 & 0.305 \\
Chl-a & -0.06 & -0.275 & 0.174 & 0.787 \\
SS & $\mathbf{0 . 7 8 8}$ & 0.224 & -0.272 & -0.11 \\
& 0.23 & 0.246 & 0.419 & -0.278 \\
Factors & 1 & Variance explained by each factor & 4 \\
\% of Variance & 23.72 & 2 & 3 & 9.59 \\
& $\%$ Total variance explained & 13.99 & 66.46 \\
\hline Ex & & 19.16 & & \\
\hline
\end{tabular}

Extraction method: Principal component analysis. Rotation method: Varimax with Kaiser Normalization. a: Rotation converged in 5 iterations. 
run physicochemical and biological processes in water [27]. Similarly, suspended solids mean value was significantly higher in this period than the previous period with the highest value $27 \mathrm{mg} / \mathrm{l}$. The continuous increase in SS indicates that the construction and agricultural activities in the basin are increasing. The monsoon stormwater runoff causes soil erosion from non-point sources can increase the SS concentration in water body [10] [28]. The decrease in Chl-a was observed in comparing to the first period (1998-2003) in the third period but wa higher than the second period (2004-2009). Water transparency was slightly improved throughout the monitoring periods. Salinity of lagoon plays an important role which varies with inflow of freshwater from streams and runoff, and circulation to the sea water. The salinity in Lake Hwajipo was the lowest in the third period. This could be related to the low water circulation between North and South due to the narrow connecting channel [16]. The nutrient ( $\mathrm{N}$ and $\mathrm{P}$ ) components were slightly lower in the third period of the study as well as SD. The nutrients in the water bodies are the byproduct of the human activities in the basin which have a large localized effect on water chemistry. Land use plays significant role on the hydrology system of the water body and its water quality [2]. DO in water depends on water circulation and photosynthesis activities by phytoplankton in lagoon.

Principal component analysis in this study helped to identify which components/factors were influencing the water quality in different periods. In the first two periods, 1998-2003 and 2004-2005, F1 was mainly contributed by Cond and salinity. These two parameters are related to the physical source variabily. TN and Chl-a in first period and TP, Temp and Chl-a in the second period were the F2 contributing variables. But in the third period TP and Chl-a showed the highest correlation with first factor and contributed $23.72 \%$ of the total variance. The sources of TP and TN can be interpreted as point sources (domestic, industrial wastewater etc.) and non-point sources (forests agricultural land etc.) [21]. Sedimentation of nutrients and their release due to suspension and re-suspension also plays important role [29] [30]. Internal and external loading of nutrients are the big factors to be considered to achieve the sustainable water environment of the lagoon. Reclamation of water body through dredging and enhancing water circulation could be the long term goals [31] [32] [33].

In this study, the water quality of Lake Hwajinpo in three different time periods was demonstrated by analyzing physicochemical parameters statistically. And the results showed that the lagoon water quality was distinctly different in each period. The highly significant parameters in the first period (1998-2003) and second period (2004-20090 were less significant in the third period (2013-2015). Total phosphorus and chlorophyll-a were the two water quality parameters highly significant in the third period.

\section{Conclusions}

Long-term water quality data was analyzed to understand how the physico- 
chemical water quality varied throughout 1998-2015 in Lake Hwajinpo, Korea. The descriptive statistics of the three periods suggested that there was no clear pattern of variation of the water quality parameters. Temperature and suspended solids showed the highest mean values in the third period (2013-2015). Meanwhile, second period (2004-2005) observed the highest mean values of conductivity and salinity. And first period (1998-2003) showed the highest mean values of chlorophyll-a, nutrients etc. Similarly, the PCA/FA results demonstrated no clear pattern of the most important water quality parameters. PCA method explained about $70 \%$ variations of each data. Factors deducted in this process, suggested that the total phosphorus and Chlorophyll-a were the most significant parameters in 2013-2015 with $23.72 \%$ total variance. And the other parameters were dissolved oxygen and nitrate nitrogen in F2 with 19.16\% and conductivity and salinity in F3 with $13.99 \%$ total variance. In contrast, conductivity and salinity were the most significant variables in F1 (22.93\% of total variance) in 1998-2003 and F1 (20.77\% of total variance) in 2004-2009.

Therefore, continuous monitoring of water quality and data analyses are required to understand the water quality status of water bodies. This study will be helpful to water managers and administrator to formulate plan to achieve healthy water through sustainable management.

\section{Acknowledgements}

This study was supported by 2015 Research Grant (number 201510016) from Kangwon National University.

\section{References}

[1] Ouillon, S., Douillet, P., Fichez, R. and Panché, J. (2005) Enhancement of Regional Variations in Salinity and Temperature in a Coral Reef Lagoon, New Caledonia. Comptes Rendus Geoscience, 337, 1509-1517. https://doi.org/10.1016/j.crte.2005.08.005

[2] Limoges, A., de Vernal, A. and Ruiz-Fernandez, A. (2015) Investigating the Impact of Land Use and the Potential for Harmful Algal Blooms in a Tropical Lagoon of the Gulf of Mexico. Estuarine, Coastal and Shelf Science, 167, 549-559. https://doi.org/10.1016/j.ecss.2015.11.005

[3] Das, L, Meher, J.K. and Dutta, M. (2016) Construction of Rainfall Change Scenarios over the Chilka Lagoon in India. Atmospheric Research, 182, 36-45.

https://doi.org/10.1016/j.atmosres.2016.07.013

[4] Newton, A., Icely, J.D., Falcao, M., Nobre, A., Nunes, J.P., Ferreira, J.G. and Vale, C. (2003) Evaluation of Eutrophication in the Ria Formosa coastal lagoon, Portugal. Continental Shelf Research, 23, 1945-1961. https://doi.org/10.1016/j.csr.2003.06.008

[5] Roselli, L. Fabbrocini, A., Manzo, C. and D’Adamo, R. (2009) Hydrological Heterogeneity, Nutrient Dynamics and Water Quality of a Non-Tidal Lentic Ecosystem (Lesina Lagoon, Italy). Estuarine, Coastal and Shelf Science, 84, 539-552. https://doi.org/10.1016/j.ecss.2009.07.023

[6] Apau, J., Appiah, S.K. and Marmon-Halm, M. (2012) Assessment of Water Quality Parameters of Kpeshi Lagoon of Ghana. Journal of Science and Technology, 32, $22-31$. 
[7] Yoon, S.O., Hwang, S.G., Park, C.S., Kim, H.S. and Moon, Y.R. (2008) Landscape Changes of Coastal Lagoons during the 20th Century in the Middle East Coast, South Korea. Journal of the Korean Geographical Society, 43, 449-465.

[8] Kim, J.Y., Bhatta, K., Rastogi, G., Muduli, P.R., Do, Y., Kim, D.K., Pattnaik, A.K. and Joo, G.J. (2016) Application of Multivariate Analysis to Determine Spatial and Temporal Changes in Water Quality after New Channel Construction in the Chilika Lagoon. Ecological Engineering, 90, 314-319. https://doi.org/10.1016/j.ecoleng.2016.01.053

[9] Lee, M.B., Kim, N.S. and Lee, G.R. (2006) The Distribution and Geomorphic Changes of Natural Lakes in East Coast of Korea. Journal of the Korean Association of Regional Geographers, 12, 449-460.

[10] Heo, W.M., Kim, B.C. and Jun, M.S. (1999) Evaluation of Eutrophication of Lagoons in the Eastern Coast of Korea. Korean Journal of Limnology, 32, 141-151.

[11] Kjerfve, B. (1986) Comparative Oceanography of Coastal Lagoons. In: Wolfe, D.A., Ed., Eastuarine Variability, Academic Press, New York, 63-81. https://doi.org/10.1016/B978-0-12-761890-6.50009-5

[12] Dixon, W. and Chiswell, B. (1996) Review of Aquatic Monitoring Program Design. Water Research, 30, 1935-1948. https://doi.org/10.1016/0043-1354(96)00087-5

[13] Bierman, P., Lewis, M., Ostendorf, B. and Tanner, J. (2011) A Review of Methods for Analysing Spatial and Temporal Patterns in Coastal Water Quality. Ecological Indicators, 11, 103-114. https://doi.org/10.1016/j.ecolind.2009.11.001

[14] Harris, J.M. and Vinobaba, P. (2013) Assessment the Present Status of Batticaloa Lagoon, Sri Lanka by means of Water Quality, Fish Diversity Indices and Pollution Indicating Planktons. Journal of Biodiversity and Endangered Species, 1, 105.

[15] WREO, Wonju Regional Environmental Office (2013) Lakes Environmental and Ecology Research.

[16] Heo, W.M., Kwon, S.Y., Lee, J.I., Kim, D.S. and Kim, B.C. (2004) The Limnological Survey of a Coastal Lagoon in Korea (3): Lake Hwajinpo. Korean Journal of Limnology, 37, 12-25.

[17] Heo, W.M., Choi, S.G., Kwak, S.J., Bhattrai, B.D. and Lee, E.J. (2011) The Study of Water Environment Variations in Lake Hwajinpo. Korean Journal Limnology, 44, 9-21.

[18] Kim, B.H., Won, D.H. and Kim, Y.J. (2012) Spring Bloom of Skeletonema costatum and Lake Trophic Status in the Hwajinpo Lagoon, South Korea. Korean Journal of Limnology, 45, 329-339.

[19] Thurton, G.D. and Spengler, J.D. (1985) A Quantitative Assessment of Source Contributions to Inhalable Particulate Matter Pollution in Metropolitan Boston. Atmospheric Environment, 19, 9-25. https://doi.org/10.1016/0004-6981(85)90132-5

[20] Ouyang, Y., Nkedi-Kizza, P., Wu, Q.T., Shinde D. and Huang, C.H. (2006) Assessment of Seasonal Variations in Surface Water Quality. Water Research, 40, 3800-3810. https://doi.org/10.1016/j.watres.2006.08.030

[21] Shrestha, S. and Kazama, F. (2007) Assessment of Surface Water Quality using Multivariate Statistical Techniques: A Case Study of the Fuji River Basin, Japan. Environmental Modelling \& Software, 22, 464-475. https://doi.org/10.1016/j.envsoft.2006.02.001

[22] APHA (1992) Standard Methods for the Examination of Water and Wastewater. 18th Edition, American Public Health Association, Washington DC, 1801.

[23] Simeonov, V., Stratis, J.A., Samara, C., Zachariadis, V.D., Anthemidis, A., Sofoniou, 
M. and Kouimtzi, Th. (2003) Assessment of the Surface Water Quality in Northern Greece. Water Research, 37, 4119-4124. https://doi.org/10.1016/S0043-1354(03)00398-1

[24] Bhattrai, B.D., Kwak, S.J. and Heo, W.M. (2015) Assessment of Water Quality Variations under Non-Rainy and Rainy Conditions by Principal Component Analysis Techniques in Lake Doam Watershed, Korea. Journal of Ecology and Environment, 38, 1-12. https://doi.org/10.5141/ecoenv.2015.016

[25] Bhattrai, B.D., Kwak, S.J., Choi, G.S. and Heo, W.M. (2017) Long-Term Changes of Physicochemical Water Quality in Lake Youngrang, Korea. Korean Journal of Ecology and Environment, 50, 169-185. https://doi.org/10.11614/KSL.2017.50.1.169

[26] Singh, K.P., Malik, A., Mohan, D. and Sinha, S. (2005) Water Quality Assessment and Apportionment of Pollution Sources of Gomti River (India) using Multivariate Statistical Techniques-A Case Study. Analytica Chimica Acta, 538, 355-374. https://doi.org/10.1016/j.aca.2005.02.006

[27] Jayakumar, R., Steger, K., Chandra, T.S. and Seshadri, S. (2013) An Assessment of Temporal Variations in Physicochemical and Microbiological Properties of Barmouths and Lagoons in Chennai (Southeast Coast of India). Marine Pollution Bulletin, 70, 44-53. https://doi.org/10.1016/j.marpolbul.2013.02.005

[28] Trabelsi, E.L.B., Armi, Z., Trabelsi-Annabi, N., Shili, A. and Maiz, N.B. (2013) Water Quality Variables as Indicators in the Restoration Impact Assessment of the North Lagoon of Tunis, South Mediterranean. Journal of Sea Research, 79, 12-19. https://doi.org/10.1016/j.seares.2013.01.003

[29] Conley, D.J., Stockenberg, A., Carman, R., Johnstone, R.W., Rahm, L. and Wul, F. (1997) Sediment-Water Nutrient Fluxes in the Gulf of Finland, Baltic Sea. Estuarine, Coastal and Shelf Science, 45, 591-598. https://doi.org/10.1006/ecss.1997.0246

[30] Schallenberg, M., Larned, S.T., Hayward, S. and Arbuckle, C. (2010) Contrasting Effects of Managed Opening Regimes on Water Quality in Two Intermittently Closed and Open Coastal Lakes. Estuarine, Coastal and Shelf Science, 86, 587-597. https://doi.org/10.1016/j.ecss.2009.11.001

[31] Markou, D.A., Sylaios, G.K., Tsihrintzis, V.A., Gikas, G.D. and Haralambidou, K. (2007) Water Quality of Vistonis Lagoon, Northern Greece: Seasonal Variation and Impact of Bottom Sediments. Desalination, 210, 83-97. https://doi.org/10.1016/j.desal.2006.05.035

[32] Perilla, O.L.U., Gómez, A.G., Gómez, A.S., Díaz, C.Á. and Cortezón, J.A.R. (2012) Methodology to Assess Sustainable Management of Water Resources in Coastal Lagoons with Agricultural Uses: An Application to the Albufera Lagoon of Valencia (Eastern Spain). Ecological Indicators, 13, 129-143.

https://doi.org/10.1016/j.ecolind.2011.05.019

[33] Acquavita, A., Aleffi, I.F., Benci, C., Bettoso, N., Crevatin, E., Milani, L., Tamberlich, F., Toniatti, L., Barbieri, P., Licen, S. and Mattassi, G. (2015) Annual Characterization of the Nutrients and Trophic State in a Mediterranean Coastal Lagoon: The Marano and Grado Lagoon (Northern Adriatic Sea). Regional Studies in Marine Science, 2, 132-144. https://doi.org/10.1016/j.rsma.2015.08.017 